\title{
KONSEP PROPESI KEGURUAN DAN ILMU PENDIDIKAN
}

\author{
HELPINA \\ Email: 2010128120010@mhs.ulm.ac.id \\ Program Studi Pendidikan IPS Fakultas Keguruan dan Ilmu Pendidikan \\ Universitas Lambung Mangkurat \\ Banjarmasin
}

\begin{abstract}
Abstrak
Guru merupakan sebuah propesi karena propesi guru memiliki kode etik yang berfungsi sebagai norma hukum dan sekaligus sebagai norma masyarakat. propesi guru ditandai oleh orientasinya yang lebih kepada masyarakat dari pada pribadi.seorang guru harus mampu meningkatkan daya belajar.

Suatu pekerjaan dikatakan sebagi propesi jika ia lakukan full time, didasarkan panggilan hidup, terikat norma dan aturan memiliki derajat otonomi tinggi, melakukan pengembangan diri secar terus menerus dan memiliki kode etik propesi.tenaga pendidikan atau guru merupakan anggota masyarakat yang mengapdikan diri dan diangkat menunjang penyelenggaraan pendidikan, selain itu guru juga bertugas untuk melaksanakan administrasi, pengelolaan, pengembangan pengawasan, dan pelayanan teknis untuk menunjang proses pendidikan.

Guru merupakan komponen penting dalam proses pembelajaran. dengaan keprofesionalitasnya itu guru akan mampu memperbaiki proses pembelajaran sehingga dapat dengan otomatis pula dapat meningkatkan mutu pendidikan.sebab guru professional tentunya akan memberikan seluruh kemampuannya untuk kepentingan kemajuan mutu pendidikan itu sendiri .semakin profesioal guru maka semakin dapat memperbaiki proses pembelajaran dan semakin meningkat kualitas pencapaian tujuan pembelajaran.
\end{abstract}




\section{PENDAHULUAN}

Propesi merupakan suatu pekerjaan atau jabatan yang menuntut keahlian yang didapat melalui pendidikan dan latihan tertentu,yang memiliki persyaratan khusus yaitu tanggung jawab dan kode etik tertentu.propesi merupakan pekerjaan yang bersifat propesional yang berbeda dengan pekerjaan yang lain karena propesi memerlukan kemampuan dan keahlian khusus dalam melaksanakan propesinya.Propesi juga dapat diartikan sebagai suatu jabatan atau pekerjaan tertentu yang mensyaratkan pengetahuan dan keterampilan khusus yang diperoleh dari pendidikan akademis yang intensif. (Heri Susanto, 2020: 13).

Guru adalah pendidik propesional dengan tugas utama mendidik, mengajar, membimbing, mengarahkan, melatih, menilai dan mengevaluasi peserta didik pada pendidikan anak usia dini,jalur pendidikan formal, pendidikan dasar dan pendidikan menengah.Dosen adalah pendidik propesional dan ilmuan dengan tugas utama mentransformasikan, mengembangkan, dan menyebarluaskan ilmu pengetahuan, teknologi, dan seni melalui pendidikaan, penelitian, dan pengabdian kepada masyarakat. (Heri Susanto, 2020: 12).

Guru merupakan suatu propesi yang beraeti suatu jabatan yang memerlukan keahlian khusus dan tidak dapat dilakukan oleh sembarang orang diluar bidang pendidikan.

\section{PERAN GURU SEBAGAI SEBUAH PROFESI}

Guru merupakan sebuah propesi karena propesi guru memiliki kode etik yang berfungsi sebagai norma hukum dan sekaligus sebagai norma masyarakat.propesi guru ditandai oleh orientasinya yang lebih kepada masyarakat dari pada pribadi.seorang guru harus mampu meningkatkan daya belajar.

Suatu pekerjaan dikatakan sebagi propesi jika ia lakukan full time,didasarkan panggilan hidup, terikat norma dan aturan memiliki derajat otonomi tinggi, melakukan pengembangan diri secar terus menerus dan memiliki kode etik propesi. tenaga pendidikan atau guru merupakan anggota masyarakat yang mengapdikan diri dan diangkat menunjang penyelenggaraan pendidikan, selain itu guru juga bertugas untuk melaksanakan 
administrasi, pengelolaan, pengembangan pengawasan, dan pelayanan teknis untuk menunjang proses pendidikan.( Fadillah, A. B. KONSEP PROFESI GURU.)

Berdasarkan UU RI NO.14 Tahun 2005 tentang Guru dan Dosen Pasal 1, Guru adalah pendidik propesional dengan tugas utama mendidik, mengajar, membimbing, mengarahkan, melatih, menilai dan mengevaluasi peserta didik pada pendidikan anak usia dini,jalur pendidikan formal, pendidikan dasar dan pendidikan menengah.Dosen adalah pendidik propesional dan ilmuan dengan tugas utama mentransformasikan ,mengembangkan, dan menyebarluaskan ilmu pengetahuan, teknologi, dan seni melalui pendidikaan, penelitian, dan pengabdian kepada masyarakat. (Heri Susanto, 2020:37).

Langkah pemerintah memberlakukan Undang-Undang Nomor 14 Tahun 2005 Tentang Guru dan Dosen dimaksudkan untuk membangun propesionalisme guru.Substansi materi yang diatur dalam undang-undang ini adalah memberdayakan dan meningkatkan kualitas guru secara terencana,terarah,dan berkesinambungan sehingga propesi guru perlu dikembaangkan sebagai propesi yang sejahtera,bermartabat,dan terlindungi dalam melaksanakan tugas kepropesionalan, guru memiliki kebebasan dan memberikan penilaian dan ikut menentukan kelulusan, penghargaan, dan atau sanksi kepada peserta didik sesuai dengan kaidah pendidikan,kode etik guru ,dan peraturan perundang-undangan.

( Komara, E. (2016).1(2).)

Peran Guru menurut Gary Flewelling dan William Higginson yaitu:

1. Memberikan stimulasi kepada siswa dengan menyediakan tugas-tugas pembelajaran yang kaya dan terancang dengan baik untuk meningkatkan perkembangan intelektual,emosional,spiritual,dan sosial.

2. Berinteraksi dengan siswa untuk mendorong keberanian, mengilhami, menantang, berdiskusi, berbagi, menjelaskan, menegaskan, merefleksi, menilai, dan merayakan perkembangan, pertumbuhan dan keberhasilan.

3. Menunjukkan manfaat yang diperoleh dari mempelajari suatu pokok bahasan.

4. Berperan sebagai seseorang yang membantu, seseorang yang mengerahkan dan memberi penegasan, seseorang yang memberi jiwa dan mengilhami siswa dengan cara membangkitkan rasa ingin tahu, rasa antusias, gairah dari seorang (Kirom, A. (2017). 69-80.) 
Hak guru yaitu suatu yang harus didapatkan olehnya setelah ia melaksanakan kewajibannya sebagaai guru,adapun hak yang dimili oleh seorang guru sebagai berikut:

1. Memperoleh penghasilan diatas kebutuhan hidup minimum dan jaminan kesejahteraan sosial.

2. Mendapatkan promosi dan penghargaan sesuai dengan tugas dan prestasi kerja.

3. Memproleh perlindungan dalam melaksanakan tugas dan ha katas kekayaan intelektual.

4. Memproleh kesempataan untuk meningkatkan kompetensi.

5. Memproleh dan mendapatkan sarana dan prasarana pembelajaran untuk meenunjang kelancaran tugas keprofesionalan.

6. Memiliki kebebasan dalam memberikan penilaian dan ikut menentukan kelulusan,penghargaan,dan atau sanksi kepada peserta didiks sesuai dengan kaidah pendidikan,kode etik, dan peraturan perundang-undangan.

7. Memproleh rasa aman dan jaminan keselamataan dalaam melaksanakan tugas.

8. Memiliki kebebasan untuk beerserikatdalam orgaanisasi propesi.

9. Memiliki kesempatan untuk berperan dalam penentuan kebijakan pendidikan.

10. Memproleh kesempatan untuk mengembangkan dan meningkatkan kualifikasi akademik dan kompetensi.

11. Memproleh pelatihan dan pengembangan propesi dalam bidangnya.

Kewajiban seorang guru Menurut Roestiyah N.K., (1989) yaitu:

1. Menyerahkan kebudayaan kepada anak didik berupa kepandaian, kecakapan, dan pengalaman-pengalaman.

2. Membentuk kepribadian anak yang harmonis, sesuai cita-cita dan dasar negara kita pancasila.

3. Menyiapkan anak menjadi warga negara yang baik sesuai undang-undang pendidikan. 
4. Sebagai perantara dalam belajar. Didalam proses belajar guru hanya sebagai perantara/medium, anak harus berusaha sendiri mendapatkan suatu pengertian, sehingga timbul perubahan dalam pengetahuan, tinggkah laku, dan sikap.

5. Guru adalah sebagai pembimbing, untuk membawa anak didik ke arah kedewasaan, tidak dapat membentuk anak menurut sekehendaknya.

6. Guru sebagai penghubung antar sekolah dan masyarakat. Anak nantinya akan hidup dan bekerja, serta mengabdikan diri dalam masyarakat, dengan 40 Heri Susanto demikian anak harus dilatih dan dibiasakan disekolah dibwah pengawasan guru

7. Sebagai penegak disiplin, guru menjadi contoh dalam segala hal, tata tertib dapat berjalan bila guru dapat menjalani terlebih dahulu.

8. Guru sebagai administrator dan manajer. Disamping mendidik, seorang guru harus dapat mengerjakan urusan tata usaha seperti membuat buku kas, daftar induk, rapor, daftar gaji dan sebagainya, serta dapat mengkoordinasi segal pekerjaan di sekolah secara demokratis, sehingga suasana pekerjaan penuh dengan rasa kekeluargaaan

9. Pekerjaan guru sebagai suatu profesi.

10. Guru sebagai perencana kurikulum. Guru menghadapin anak-anak setiap hari, gurulah yang paling tau kebutuhan anak-anak dan masyarakat sekitar, maka dalam penyusunan kurikulum, kebutuhan ini tidak boleh di tinggalkan.

11. Guru sebagai pemimpin (guidance worker). Guru mempunyai kesepatan dan tanggung jawab dalam banyak situasi untuk membimbing anak kearah pemecah soal, membentuk keputusan, dan menghadapkan anak-anak pada problem.

12. Guru sebagai seponsor dalam kegiatan anak-anak. Guru harus turut aktif dalam segala aktivitas anak, misalnya ekstrakurikuler membentuk kelompok belajar dan sebagainya.(Heri susanto,2020:49) 


\section{GURU INDONESIA DAN TANTANGAN PROFESIONALISME}

Guru merupakan komponen penting dalam proses pembelajaran.dengaan keprofesionalitasnya itu guru akan mampu memperbaiki proses pembelajaran sehingga dapat dengan otomatis pula dapat meningkatkan mutu pendidikan. sebab guru professional tentunya akan memberikan seluruh kemampuannya untuk kepentingan kemajuan mutu pendidikan itu sendiri.semakin profesioal guru maka semakin dapat memperbaiki proses pembelajaran dan semakin meningkat kualitas pencapaian tujuan pembelajaran. (Sastrawan, K. B. (2016). 65-73.)

Kompetensi guru merupakan salah satu factor yang mempengaruhi terjadinya tujuan pembelajran dan pendidikan disekolah,namun kompetensi guru tidak berdiri sendiri melainkan dipengaruhi oleh factor seperti latar belakang pendidikan,pengalaman mengajar dan lama mengajar.

Adapun standar kompetensi yang harus dimiliki oleh seorang guru agar mendapat sertifikasi untuk melaksanakan tugas dan wewenang sebagi tenaga kependidikan yaitu meliputi:

1. Kompetensi Pedagogik, yang merupakan suatu perfomasi (kemampuan) seseorang dalam bidang ilmu pendidikan. Untuk menjadi guru profesional harus memiliki kompetensi pedagogic. Seorang guru harus memiliki pengetahuan dan pemahaman serta kemampuan dalam keterampilan pada bidang propesi kependidikan.

2. Kompetensi Kepribadian, merupakan suatu masalah yang abstrak, hanya dapat dilihat lewat penampilan, tindakan, ucapan, dan cara berpakaian seseorang. Setiap orang memiliki kepribadian yang berbeda. Kompetensi ini harus dimiliki seorang guru karena penampilan kedewasaan layak diteladani, memiliki sikap dan kemampuan memimipin dan demokratis serta mengayomi peseta didik.

3. Kompetensi sosial, merupakan salaah satu dari Sembilan kecerdasan (logika, bahasa, music, raga, ruang, pribadi, alam, dan kuliner. Semua kecerdasan itu 
dimiliki oleh seseorang, hanya mungkin beberapa diantaranya menonjol dan yang lain biasa saja .

4. Kompetensi Propesional, merupakan suatu kemampuan sesuai dengan keahliannya. Seorang guru harus menyampaikan sesuatu keahliannya kepada pesera didik dalam rangka menjalankan tugas dan propesinya.

( Ismail, M. I. (2010).), 44-63.)

\section{SIMPULAN}

Propesi merupakan suatu pekerjaan atau jabatan yang menuntut keahlian yang didapat melalui pendidikan dan latihan tertentu, yang memiliki persyaratan khusus yaitu tanggung jawab dan kode etik tertentu.

Guru adalah pendidik propesional dengan tugas utama mendidik ,mengajar, membimbing, mengarahkan, melatih, menilai dan mengevaluasi peserta didik pada pendidikan anak usia dini,jalur pendidikan formal,pendidikan dasar dan pendidikan menengah.

Guru merupakan komponen penting dalam proses pembelajaran. dengaan keprofesionalitasnya itu guru akan mampu memperbaiki proses pembelajaran sehingga dapat dengan otomatis pula dapat meningkatkan mutu pendidikan. sebab guru professional tentunya akan memberikan seluruh kemampuannya untuk kepentingan kemajuan mutu pendidikan itu sendiri. semakin profesioal guru maka semakin dapat memperbaiki proses pembelajaran dan semakin meningkat kualitas pencapaian tujuan pembelajaran. 


\section{REFERENSI}

Efendi, I., Prawitasari, M., \& Susanto, H. (2021). Implementasi Penilaian Pembelajaran Pada Kurikulum 2013 Mata Pelajaran Sejarah. Prabayaksa: Journal of History Education, 1(1), 21-25.

Susanto, H. (2020). Profesi Keguruan. Banjarmasin: FKIP Universitas Lambung Mangkurat.

Susanto, H., \& Akmal, H. (2018). Efektivitas Penggunaan Aplikasi Pembelajaran Berbasis Mobile Smartphone Sebagai Media Pengenalan Sejarah Lokal Masa Revolusi Fisik Di Kalimantan Selatan Pada Siswa Sekolah Menengah Atas. HISTORIA: Jurnal Program Studi Pendidikan Sejarah, 6(2), 197-206.

Susanto, H., Irmawati, I., Akmal, H., \& Abbas, E. W. (2021). Media Film Dokumenter Masuknya Islam Ke Nusantara dan Pengaruhnya Terhadap Keterampilan Berpikir Kritis Siswa. HISTORIA: Jurnal Program Studi Pendidikan Sejarah, 9(1).

Syaharuddin, S., \& Susanto, H. (2019). Sejarah Pendidikan Indonesia (Era Pra Kolonialisme Nusantara sampai Reformasi). Banjarmasin: FKIP Universitas Lambung Mangkurat.

Ismail, M. I. (2010). Kinerja dan kompetensi guru dalam pembelajaran. Lentera Pendidikan: Jurnal Ilmu Tarbiyah dan Keguruan, 13(1), 44-63.

Kirom, A. (2017). Peran guru dan peserta didik dalam proses pembelajaran berbasis multikultural. Al Murabbi, 3(1), 69-80

Sastrawan, K. B. (2016). Profesionalisme guru dalam upaya meningkatkan mutu pembelajaran. Jurnal Penjaminan Mutu, 2(2), 65-73. 